\title{
Article \\ Calcined Oyster Shell Powder as a Natural Preservative for Maintaining Quality of White Shrimp (Litopenaeus vannamei)
}

\author{
Wen-Chien Lu ${ }^{1,+}{ }^{,}$Chien-Shan Chiu ${ }^{2,+}$, Chang-Wei Hsieh ${ }^{3} \mathbb{D}$, Yung-Jia Chan ${ }^{4}$, Zeng-Chin Liang ${ }^{5}$, \\ Chiun-C. Roger Wang ${ }^{6}$, Amanda Tresiliana Mulio ${ }^{6}$, Dung Huynh Thi Le ${ }^{7}$ and Po-Hsien Li ${ }^{6, *(1)}$
}

1 Department of Food and Beverage Management, Chung-Jen Junior College of Nursing, Health Sciences and Management, 217, Hung-Mao-Pi, Chia-Yi City 60077, Taiwan; m104046@cjc.edu.tw

2 Department of Dermatology, Taichung Veterans General Hospital, 1650 Section 4 Taiwan Boulevard, Xitun District, Taichung 40705, Taiwan; chienshan@vghtc.gov.tw

3 Department of Food Science and Biotechnology, National Chung Hsing University, 145 Xingda Road, South District, Taichung 40227, Taiwan; welson@nchu.edu.tw

4 College of Biotechnology and Bioresources, Da-Yeh University, 168, University Road, Dacun, Changhua 51591, Taiwan; chanyungjia@gmail.com

5 Department of Medicinal Botanical and Health Applications, Da-Yeh University, 168, University Road, Dacun, Changhua 51591, Taiwan; zcliang@mail.dyu.edu.tw

6 Department of Food and Nutrition, Providence University, 200, Section 7, Taiwan Boulevard, Shalu District, Taichung City 43301, Taiwan; jcwang@pu.edu.tw (C.-C.R.W.); tresiliana@gmail.com (A.T.M.)

7 Faculty of Food Science and Technology, Ho-Chi-Minh City University of Food Industry, 140, Le Trong Tan Street, Tay Thanh Ward, Tan Phu District, Ho-Chi-Minh City 700000, Vietnam; dunghtl@hufi.edu.vn

Citation: Lu, W.-C.; Chiu, C.-S.; Hsieh, C.-W.; Chan, Y.-J.; Liang, Z.-C.; Wang, C.-C.R.; Mulio, A.T.; Le, D.H.T.; Li, P.-H. Calcined Oyster Shell Powder as a Natural Preservative for Maintaining Quality of White Shrimp (Litopenaeus vannamei). Biology 2022, 11, 334. https://doi.org/10.3390/ biology11020334

Academic Editors: Daniel Franco Ruiz, Jessica Capraro, Alessio Scarafoni and Ederlan S. Ferreira

Received: 18 January 2022

Accepted: 17 February 2022

Published: 20 February 2022

Publisher's Note: MDPI stays neutral with regard to jurisdictional claims in published maps and institutional affiliations.

Copyright: (C) 2022 by the authors. Licensee MDPI, Basel, Switzerland. This article is an open access article distributed under the terms and conditions of the Creative Commons Attribution (CC BY) license (https:// creativecommons.org/licenses/by/ $4.0 /)$.
* Correspondence: pohsien0105@pu.edu.tw; Tel.: +886-4-2632-8001 (ext. 15326)

+ These authors contributed equally to this work.

Simple Summary: The Food and Agriculture Organization of the United Nations (FAO) indicated that the average global production of oyster shell waste for the year 2019 was 3.08 million tons. Many serious problems include the emission of displeasing odors and pollution of the seaside, which are harmful to the environment. Nonetheless, a solution for this issue would be to reuse the waste and produce a product that has economic benefits and solves the environmental problems. Using calcined oyster shells as a natural preservative might solve the problem of oyster shell waste. In this study, we used calcined oyster shell powder (COSP) as a natural preservative for improving shrimp shelf-life during 12 days under refrigerated conditions. As compared with the control, COSP treatment effectively retarded $\mathrm{pH}$ change, reduced the formation of total volatile basic nitrogen, and inhibited bacterial growth during refrigerated storage. The development of preservatives for aquatic products is expected to delay the growth of and spoilage by microorganisms in the refrigerated state, thus providing more barrier protection for aquatic food safety.

Abstract: Oyster shell waste has led to many problems, including displeasing odors, pollution of the seaside, and harm to the environment. Using calcined oyster shells as a natural preservative might solve the problem of oyster shell waste. We studied the use of calcined oyster shell powder (COSP) as a natural preservative for improving shrimp shelf-life over 12 days under refrigerated conditions. As compared with the control, COSP treatment effectively retarded $\mathrm{pH}$ change, reduced the formation of total volatile basic nitrogen, and inhibited bacterial growth during refrigerated storage. In addition, shrimp muscle lipid oxidation measured by peroxide value (PV) and thiobarbituric acid (TBA) was decreased during storage. The quality was preserved up to 12 days with $2.0-4.0 \%$ COSP treatment as compared with only 6 days for un-treated shrimp. The development of preservatives for aquatic products is expected to delay growth of and spoilage by microorganisms in the refrigerated state, thus providing more barrier protection for aquatic food safety.

Keywords: white shrimp; natural preservatives; calcined oyster shell powder; total volatile basic nitrogen; shelf-life 


\section{Introduction}

Seafoods, such as fish and shellfish, are highly perishable and have a limited shelf-life after capture because of their biological composition. To avoid microbiological spoilage and enzymatic reactions, a low temperature is one of the most vital criteria, being able to reduce enzyme and microorganism activity [1]. The use of temperature regulation to preserve aquatic products is significant worldwide for both the local and export markets. Refrigerated storage is a dependable coolant that has been put to good use for centuries for cooling seafood and aquatic products both on- and offshore. Even though refrigerated storage has a bacteriostatic effect on food spoilage, it still does not entirely inhibit microbial reactions in the seafood matrix. Preservatives, such as antioxidant additives, oxygen or ion chelating agents, and antibacterial compounds, may be applied to maintain shelf-life and quality of seafoods. Therefore, the use of natural preservatives to extend the shelf-life of seafood and inhibit foodborne pathogens has received much attention [2]. Attention to natural preservatives as aquatic-product preservative agents is mostly determined by consumer's demands for more natural preservatives, no additives, and protection of the environment [3].

Recently, there has been an interesting development of reuse materials with antimicrobial properties which help to improve food safety and shelf-life. Calcined oyster shell powder (COSP) might have antimicrobial activity potential by retarding microbial growth [4]. A previous study revealed that reused oyster shell powder $(0.05,0.1$, and $0.2 \%)$ extended the shelf-life of tofu by up to 2 days during storage and enhanced its sensory value and quality; also, the microbial number was greatly reduced, which preserved tofu quality and freshness [5]. The addition of $0.05 \%$ reused oyster powder significantly enhanced the quality of kimchi during storage time; it retarded aerobic bacteria proliferation and preserved lactic acid bacteria proliferation, thus resulting in longer shelf-life while maintaining the sensory quality and crispiness of kimchi [6].

The Food and Agriculture Organization of the United Nations (FAO) indicated that the average global production of oyster shell waste for the year 2019 was 3.08 million tons, and the average output of oyster shells in Taiwan is $>160,000$ tons annually $[7,8]$. Many serious problems include the emission of displeasing odors and pollution of the seaside, which are harmful to the environment. Nonetheless, a solution for this issue would be to reuse the waste and produce a product that is economically profitable and solves the environmental problems. Lack of effective management on fishing boats, such as the working time, number of nets, and primary sorting and processing on the deck, leads to insufficient temperature control in the fishing boat cabin. This situation may increase the risk of aquatic spoilage bacteria and pathogenic bacteria attachment, breeding, and cross-contamination $[9,10]$. Discussion of the issue of aquatic food safety has increased in recent years. Hence, the use of natural food preservatives instead of synthetic preservatives. The aim of this study was to evaluate the effect of COSP on the physicochemical properties of white shrimp (Litopenaeus vannamei) under refrigerated storage conditions.

\section{Materials and Methods}

\subsection{Materials}

White shrimp (L. vannamei) with an average weight of $12.45 \pm 1.60 \mathrm{~g}$ and length of $15.82 \pm 0.68 \mathrm{~cm}$ were purchased from a local market (Wuqi Harbor, Taichung, Taiwan). The shrimp were kept in an insulated polyethylene box with a ratio of shrimp to water of 1:2 $(w / w)$ and transported to the laboratory within $2 \mathrm{~h}$.

\subsection{Preparation of COSP}

The oyster shell waste used in this study was sourced from Wuqi Harbor. The oyster shells were brushed and soaked in water for a week or more to remove salt and foreign substances. Washed oyster shells were naturally dried and then crushed. Crushed oyster shells were calcined in an electric furnace at $900{ }^{\circ} \mathrm{C}$ for $3 \mathrm{~h}$. COSP was slowly cooled to 
room temperature in the electric furnace, then pulverized to pass through a $150 \mu \mathrm{m}$ sieve. All chemical reagents used for extraction and analysis were of analytic grade.

\subsection{Dipping Solutions and Refrigerated Storage Conditions for Shrimp}

The COSP proportion in dipping solutions was $0.5 \%, 1 \%, 2 \%$, and $4 \%$ in sterile water, respectively. The shrimp were shocked with sterile crushed ice for $15 \mathrm{~min}$ and fully immersed in the four dipping solutions for $30 \mathrm{~min}$ at $4{ }^{\circ} \mathrm{C}$. Residual solution was dripped off for $1 \mathrm{~min}$ and the shrimp were kept at $4{ }^{\circ} \mathrm{C}$ until excess water was drained. Then shrimp were placed on plastic-coated wire racks inside plastic containers at $4{ }^{\circ} \mathrm{C}$ for 12 days (Figure 1).

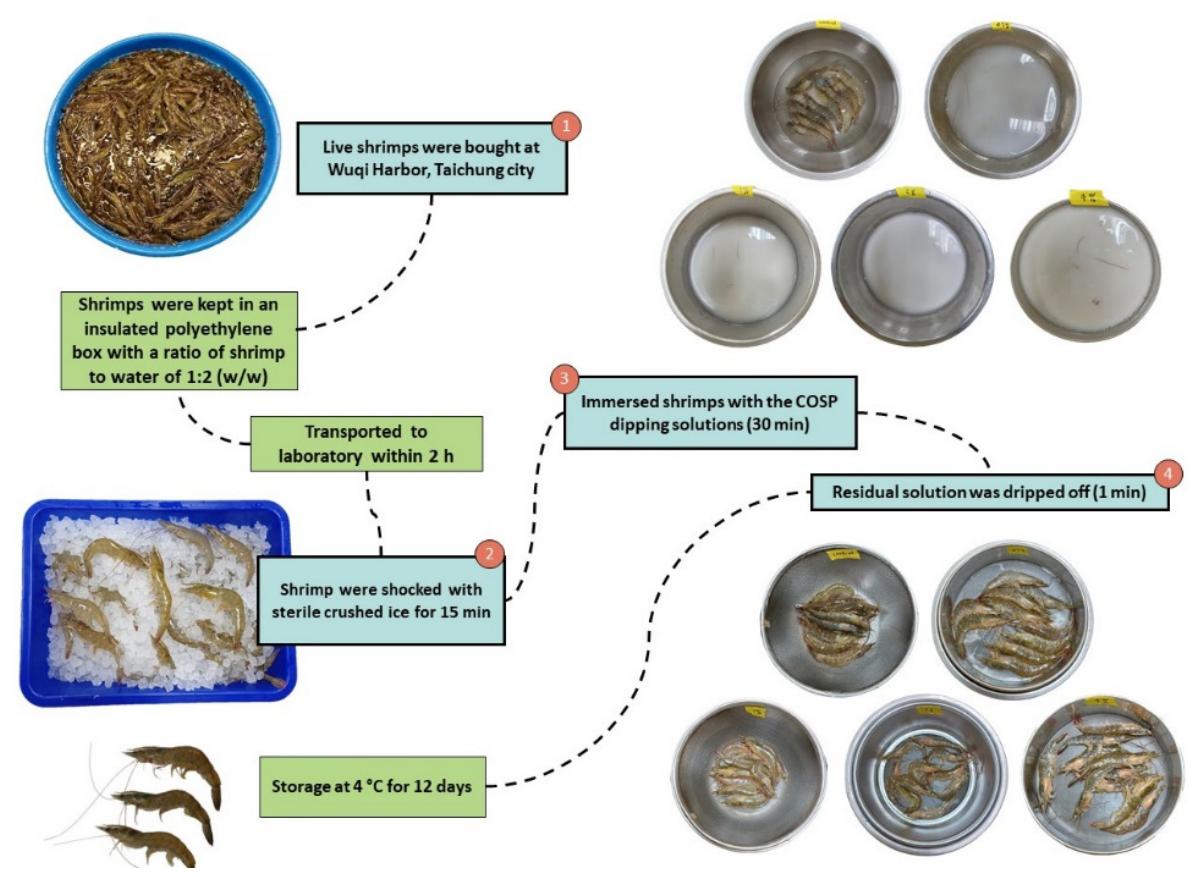

Figure 1. Shrimp samples prepared using different concentrations of COSP dipping solutions.

\subsection{COSP Characterization}

The ash (AOAC 923.03), moisture (925.10), carbohydrate (AOAC997.08), and protein (AOAC 979.09) contents in COSP samples were analyzed according to standard methods described by the AOAC (2000) [11].

\subsection{Biochemistry Quality Evaluation}

The evaluation of biochemistry quality was showed in Figure 2. $\mathrm{pH}$ of the shrimp was measured using a pH meter (Mettler, Toledo, $\mathrm{OH}, \mathrm{USA}$ ) with a mixture of $10 \mathrm{~g}$ shucking shrimp muscle in $50 \mathrm{~mL}$ distilled water.

Total volatile basic nitrogen (TVB-N) was determined as described in [12]. Approximately $5 \mathrm{~g}$ shrimp was homogenized with $15 \mathrm{~mL}$ of $4 \%$ trichloroacetic acid (w/v). A $10 \mathrm{~g}$ sample was washed in the distillation flask and $1 \mathrm{mg}$ magnesium oxide was added with a drop of silicone antifoam solution. Samples were boiled and distilled into $10 \mathrm{~mL}$ of $0.1 \mathrm{~N}$ $\mathrm{HCl}$ solutions in a $500 \mathrm{~mL}$ conical flask with added Tashiro indicator (Riedel-de Haen, Seelze, Germany). After distillation, the contents of the conical flask were titrated with $0.1 \mathrm{~N} \mathrm{NaoH}$. The TVB-N value was presented as milligram nitrogen per $100 \mathrm{~g}$ sample $(\mathrm{mg} / 100 \mathrm{~g})$. 


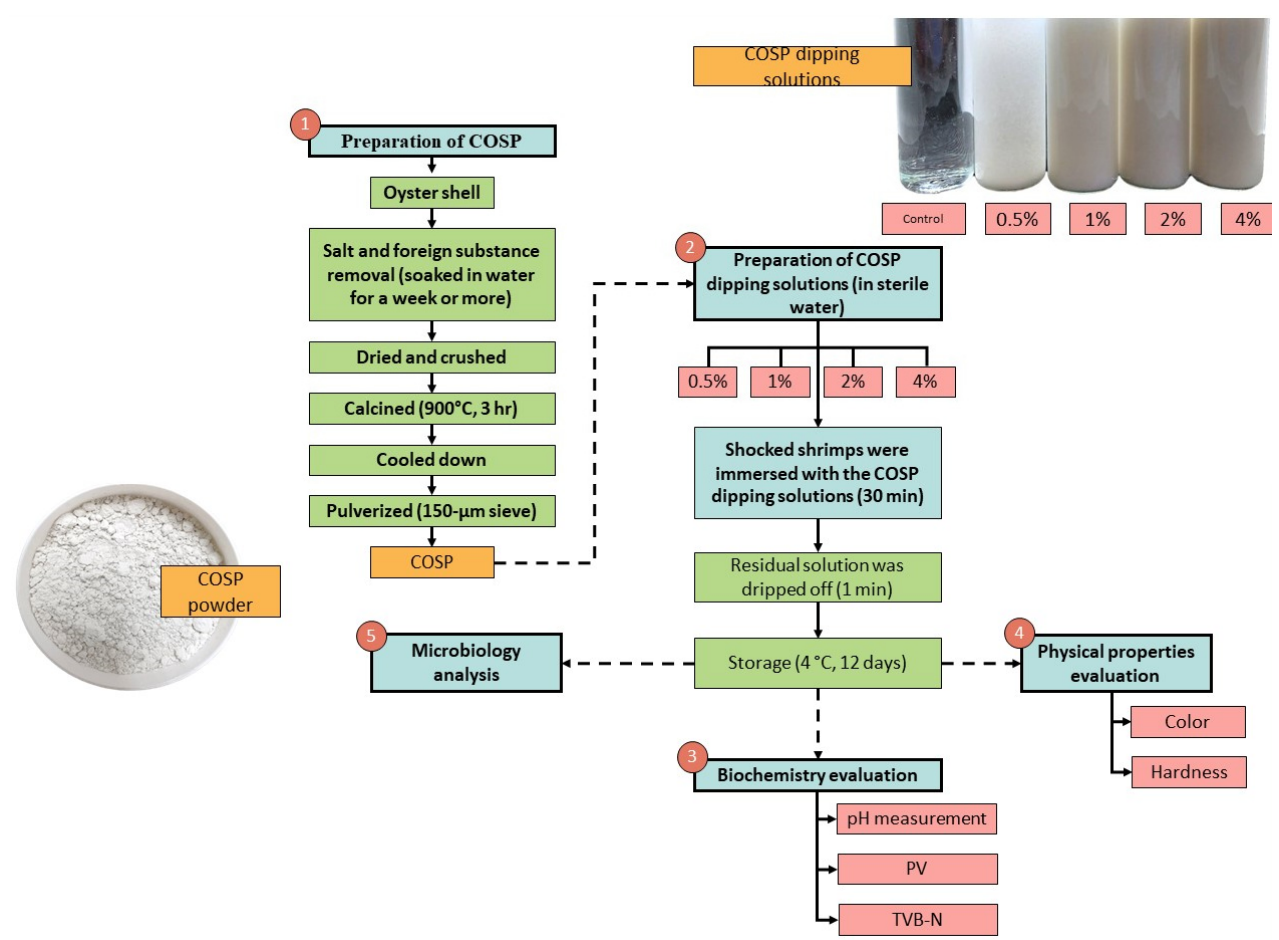

Figure 2. The experimental design of white shrimp treated with different concentrations of COSP dipping solutions.

Peroxide value (PV) was determined in the total lipid extracts by the AOCS method (1990) [13] and expressed as the uptake of meq active oxygen per kg lipid (meq/kg).

Thiobarbituric acid reactive substance (TBA) was measured based on the reactivity of the TBA with carbonyl compounds which may be increased in content because of lipid oxidation in shrimp. The absorbance of the extract with TBA reagent was measured at $532 \mathrm{~nm}$ with a UV-Vis spectrophotometer (Epoch, Biotech, VT, USA) and the constant 7.8 was used to calculate the TBA number. TBARS was expressed as mg malonaldehyde (MAD) equivalents per $\mathrm{kg}$ sample ( $\mathrm{mg} \mathrm{MAD} / \mathrm{kg}$ ).

\subsection{Physical Quality Evaluation}

The color of shrimp was analyzed using a Hunter Lab colorimeter (Hunter Associates Laboratory, Reston, VA, USA). The heads were removed from the shrimp and they were then de-shelled. Color was determined for the body muscle of the shrimp using the CIE Lab L* (lightness), $\mathrm{a}^{*}$ (redness), and $\mathrm{b}^{*}$ (yellowness) system $(n=9)$.

The hardness of the de-headed and de-shelled shrimp bodies was determined using a Texture Analyser (TA.XT., Stable Micro System, Godalming GU7, UK). The cell loading capacity and automated compression test mode operation of the Texture Analyser is $5 \mathrm{~kg}$ and $2 \mathrm{~mm} / \mathrm{s}$, respectively, with use of a stainless steel needle $(\mathrm{P} / 2 \mathrm{~N})$ probe. Texture Exponent Software was used to process the data.

\subsection{Microbiology Analysis}

The shrimp were aseptically peeled and $10 \mathrm{~g}$ of peeled muscle was homogenized in $90 \mathrm{~mL}$ sterile saline water $(0.75 \% \mathrm{NaCl})$ for $2 \mathrm{~min}$ using a Stomacher blender. The resulting homogenate was serially diluted at a ratio of 1:10 in sterile saline water. A $0.1 \mathrm{~mL}$ quantity of appropriate dilutions was spread on LB agar plates in triplicate and incubated at $30^{\circ} \mathrm{C}$ for $48 \mathrm{~h}$ to determine the total viable counts (TVC) of microbial species.

\subsection{Statistical Analyses}

Data were analyzed using Minitab 17 software. ANOVA was used to compare 3 or more groups. Tukey's test was performed at $p<0.05$ to test for statistically significant differ- 
ences. All experiments were performed in triplicate and data are expressed as means \pm SD. Pearson correlation coefficients were used to analyze the presence of a relationship between parameters. The analysis was performed with the IBM SPSS Statistics 28 software package.

\section{Results and Discussion}

\subsection{Characterization of COSP}

The COSP sample contained $98.43 \%$ ash, $0.37 \%$ moisture, $0.03 \%$ protein, and $0.12 \%$ carbohydrate, respectively. The main content in the ash was calcium oxide $(68 \%)$, which was the main antibacterial component in COSP [14].

\subsection{Effect of COSP on $\mathrm{pH}$ in Shrimp during Refrigerated Storage}

$\mathrm{pH}$ changes can be related to the formation of volatile amines from microbial activity and enzymatic ammonia production during refrigerated storage and as a spoilage indicator in marine products [15]. The original $\mathrm{pH}$ of fresh shrimp was 6.58 , which increased rapidly during storage for the control group and reached 7.68 at day 12 of storage (Table 1). Mean $\mathrm{pH}$ increased because of the production of ammonia and trimethylamine during storage. The mean $\mathrm{pH}$ for the control and $0.5 \%$ COSP treatment exceeded 7.0 after 12 days of storage. Mean pH increased slowly during storage with 1.0\%, 2.0\%, and 4.0\% treatment and reached $6.91,6.84$, and 6.80 at the end of the storage. Thus, treatment with $>1.0 \%$ COSP could extend shrimp shelf-life during refrigerated storage based on the $\mathrm{pH}$ of the shrimp. In this study, $\mathrm{pH}$ values were linearly correlated with the TVC of microbial species in the corresponding samples $\left(R^{2}=0.97,0.95,0.96,0.94\right.$, and 0.95 for control, $0.5 \%, 1.0 \%, 2.0 \%$, and $4.0 \%$ COSP-treated shrimp, respectively).

Table 1. Effect of calcined oyster shell powder (COSP) on $\mathrm{pH}$ in white shrimp during refrigerated storage.

\begin{tabular}{ccccccc}
\hline \multirow{2}{*}{ Attributes } & COSP (\%) & \multicolumn{5}{c}{ Storage Days } \\
\cline { 3 - 7 } & & $\mathbf{0}$ & $\mathbf{3}$ & $\mathbf{6}$ & $\mathbf{9}$ & $\mathbf{1 2}$ \\
\hline $\mathrm{pH}$ & Control & $6.58 \pm 0.06^{\mathrm{a}}$ & $6.67 \pm 0.03^{\mathrm{a}}$ & $7.01 \pm 0.06^{\mathrm{a}}$ & $7.48 \pm 0.07^{\mathrm{a}}$ & $7.68 \pm 0.09^{\mathrm{a}}$ \\
& $0.5 \%$ & $6.62 \pm 0.11^{\mathrm{a}}$ & $6.64 \pm 0.02^{\mathrm{a}}$ & $6.90 \pm 0.07^{\mathrm{b}}$ & $7.37^{\mathrm{a}} \pm 0.05^{\mathrm{a}}$ & $7.61 \pm 0.02^{\mathrm{a}}$ \\
& $1.0 \%$ & $6.56 \pm 0.09^{\mathrm{a}}$ & $6.60 \pm 0.04^{\mathrm{a}}$ & $6.83 \pm 0.03^{\mathrm{b}}$ & $6.88 \pm 0.04^{\mathrm{b}}$ & $6.91 \pm 0.04^{\mathrm{b}}$ \\
& $2.0 \%$ & $6.61 \pm 0.04^{\mathrm{a}}$ & $6.62 \pm 0.06^{\mathrm{a}}$ & $6.79 \pm 0.09^{\mathrm{bc}}$ & $6.82 \pm 0.05^{\mathrm{b}}$ & $6.84 \pm 0.06^{\mathrm{b}}$ \\
& $4.0 \%$ & $6.67 \pm 0.13^{\mathrm{a}}$ & $6.63 \pm 0.03^{\mathrm{a}}$ & $6.72 \pm 0.05^{\mathrm{c}}$ & $6.78 \pm 0.09^{\mathrm{b}}$ & $6.80 \pm 0.05^{\mathrm{b}}$ \\
\hline
\end{tabular}

Data are means \pm SD from triplicate experiments. ${ }^{a-c}$ Different letters indicate significant $(p<0.05)$ differences in the same row.

\subsection{Effect of COSP on TVB-N Content in Shrimp during Refrigerated Storage}

TVB-N content is an indicator of fishery spoilage and may be attributed to ammonia produced from bacterial catabolism of nitrogen-containing compounds, including compounds such as trimethylamine, dimethylamine, ammonia, and some other volatile basic nitrogen compounds [16]. The initial mean TVB-N content for the control was $12.14 \mathrm{mg} / 100 \mathrm{~g}$ and increased exponentially to $42.39 \mathrm{mg} / 100 \mathrm{~g}$ during storage (Figure 3). The increase is related to the activity of spoilage bacteria and endogenous enzymes. A mean TVB-N content of 35-40 mg/100 $\mathrm{g}$ for marine products is usually considered as spoiled [17]. Mean TVB-N content exceeded this level at 12 days refrigeration in the control, $0.5 \%, 1.0 \%$, and $2.0 \%$ COSP-treated samples, whereas $4.0 \%$ COSP-treated samples were still at $<30 \mathrm{mg} / 100 \mathrm{~g}$. COSP treatment delayed TVB-N formation as compared with the control. Similarly, a reduction of 33-50\% TVB-N content was reported for white shrimp dipped in dandelion polysaccharide and peach gum polysaccharides at the end of 12 days of storage [18]. The delay can be attributed to the protective COSP dipping solution inhibiting bacterial growth and slowing the increase in TVB-N content effectively, thus extending the preservation of shrimp. 


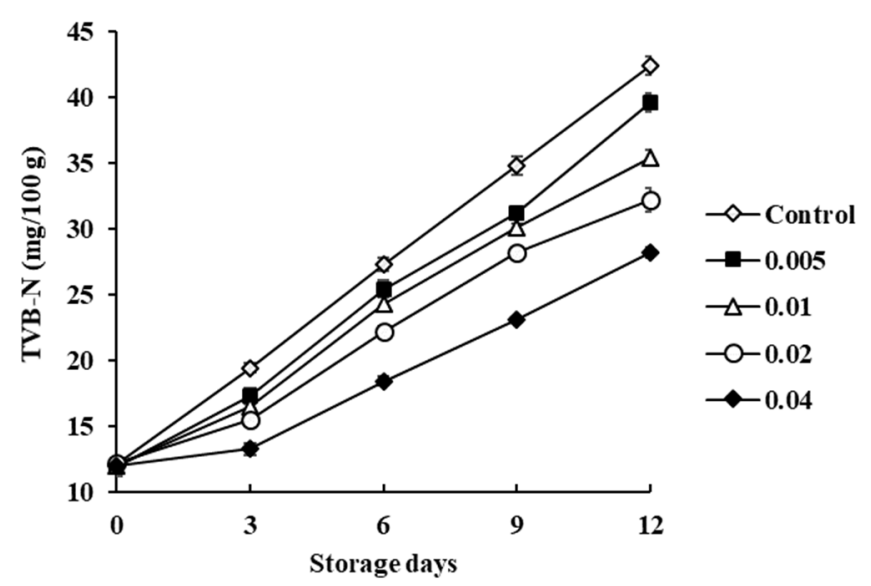

Figure 3. Effect of COSP on total volatile basic nitrogen (TVB-N) in white shrimp during refrigerated storage.

The COSP dipping solution effectively retarded TVB-N content in shrimp. After 6 days, mean TVB-N content with $0.5 \%$ and $1.0 \%$ COSP treatment reached $25.41 \mathrm{mg} / 100 \mathrm{~g}$ and $24.29 \mathrm{mg} / 100 \mathrm{~g}$, respectively, then markedly increased after 6 days, which was similar to the trend in TVC for microbial species, thus confirming the relationship between bacterial spoilage and TVB-N content. Mean TVB-N content was linearly correlated with TVC in control samples $\left(R^{2}=0.96\right)$ and in COSP-treated shrimp $\left(R^{2}=0.96,0.92,0.95\right.$, and 0.93 for $0.5 \%, 1.0 \%, 2.0 \%$, and $4.0 \%$ COSP treatment, respectively).

\subsection{Effect of COSP on PV in Shrimp during Refrigerated Storage}

The mean PV for shrimp with control and COSP treatments during storage is shown in Figure 4. The mean initial PV for the control was low $(0.13 \mathrm{meq} / \mathrm{kg})$ and increased within 9 days $(0.69 \mathrm{meq} / \mathrm{kg})$ of storage. Pseudomonas species are psychrotrophic bacteria that produce lipase and phospholipase, thus increasing free fatty acids, which are highly susceptible to oxidation and form unstable lipid hydroperoxide [17]. The increase in $\mathrm{PV}$ is attributed to the presence of free fatty acids in shrimp during refrigerated storage. It could favor oxidation during storage, followed by the formation of hydroperoxide or peroxide [15]. The PV scale for freshness of fish was suggested as $0-2 \mathrm{meq} / \mathrm{kg}$ for very good, 2-5 meq $/ \mathrm{kg}$ for good, and 8-10 meq $/ \mathrm{kg}$ for spoiled [17]. The PV increase was slower for COSP-treated than control shrimp during storage. All treated shrimp had $<2 \mathrm{meq} / \mathrm{kg}$ lipids, considered an acceptable level. The mean PV in the present study indicated that COSP treatments may retard the production of initial lipid oxidation products in shrimp. These results were had the same trends with those of chitosan-gelatin coatings film, effective in retarding lipid oxidation in trout fillets $[18,19]$. COSP might be a good barrier to oxygen permeation and act as a resistant layer between the shrimp surface and its surrounding environment, thus decreasing the diffusion of oxygen to shrimp muscle. Mean PV was linearly correlated with the TVC of microbial species for control samples $\left(R^{2}=0.92\right)$ and COSP-treated shrimp $\left(R^{2}=0.97,0.94,0.93\right.$, and 0.90 for $0.5 \%, 1.0 \%, 2.0 \%$, and $4.0 \%$ COSP treatment, respectively). 


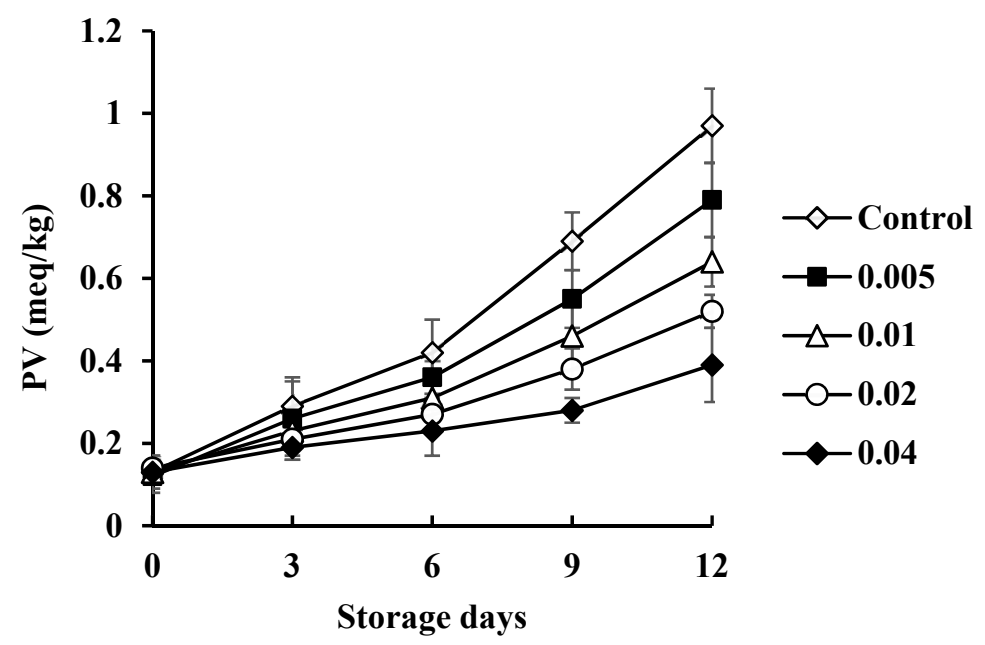

Figure 4. Effect of COSP on peroxide value (PV) in white shrimp during refrigerated storage.

\subsection{Effect of COSP on TBARS Content in Shrimp during Refrigerated Storage}

Mean TBARS content in shrimp treated with COSP during refrigerated storage is presented in Figure 5. At the beginning of storage, mean TBARS content for all samples was in the range of $0.06-0.08 \mathrm{mg} \mathrm{MAD} / \mathrm{kg}$ meat [20]. In general, TBARS content of all samples increased up to day 3 . A decrease was seen on day 6 , followed by a gradual increase up to 12 days of storage. The decreased TBARS content on day 6 was more likely due to loss of secondary lipid oxidation products previously formed within the first 3 days. Lipid oxidation is one of the deteriorative reactions causing the unacceptability of fish and shrimp products which can be initiated by autoxidation and enzymatic reactions involving lipoxygenase, peroxidase, and microbial enzymes [21]. The increase in TBARS content was lower with COSP treatment as compared with the control. A TBARS content of 1-2 mg $\mathrm{MAD} / \mathrm{kg}$ in the fishery is related to an unpleasant odor. The content reached the limit only for the control at the end of storage. TBARS content indicates the concentration of final lipid oxidation products. Lowered lipid oxidation was in accordance with lower microbial growth in shrimp treated with COSP for some doses (Table 2). COSP might have an antioxidative effect and show oxygen barrier properties in shrimp muscle during extended refrigerated storage; these could also be found during the preservation of Gourami fish fillets and chicken meat $[22,23]$. The antioxidant mechanism of COSP could be interpreted as follows: the primary amino acids of shrimp form a stable state with malondialdehyde derived from the breakdown of lipids during oxidation. We found a linear correlation between the TVC of microbial species and mean TBARS in control samples $\left(R^{2}=0.98\right)$ and COSP-treated shrimp $\left(R^{2}=0.92,0.91,0.94\right.$, and 0.93 for $0.5 \%, 1.0 \%, 2.0 \%$, and $4.0 \%$ COSP treatment, respectively).

Table 2. Effect of COSP on total viable count (TVC) of microbial species in white shrimp during refrigerated storage.

\begin{tabular}{ccccccc}
\hline & COSP (\%) & \multicolumn{5}{c}{ Storage Days } \\
\cline { 2 - 7 } & & $\mathbf{0}$ & $\mathbf{3}$ & $\mathbf{6}$ & $\mathbf{9}$ & $\mathbf{1 2}$ \\
\cline { 2 - 7 } & Control & $1.47 \pm 0.06^{\mathrm{a}} \times 10^{2}$ & $1.13 \pm 0.22^{\mathrm{a}} \times 10^{3}$ & $2.34 \pm 0.21^{\mathrm{a}} \times 10^{4}$ & $4.66 \pm 0.22^{\mathrm{a}} \times 10^{6}$ & $1.58 \pm 0.32^{\mathrm{a}} \times 10^{8}$ \\
& $0.5 \%$ & $1.21 \pm 0.11^{\mathrm{b}} \times 10^{2}$ & $6.34 \pm 0.23^{\mathrm{b}} \times 10^{2}$ & $9.17 \pm 1.50^{\mathrm{b}} \times 10^{3}$ & $2.82 \pm 0.14^{\mathrm{b}} \times 10^{5}$ & $8.22 \pm 0.66^{\mathrm{b}} \times 10^{7}$ \\
& $1.0 \%$ & $1.07 \pm 0.15^{\mathrm{b}} \times 10^{2}$ & $3.77 \pm 0.12^{\mathrm{c}} \times 10^{2}$ & $4.67 \pm 0.35^{\mathrm{c}} \times 10^{3}$ & $6.15 \pm 0.18^{\mathrm{c}} \times 10^{4}$ & $5.21 \pm 0.23^{\mathrm{c}} \times 10^{6}$ \\
& $2.0 \%$ & $7.23 \pm 0.56^{\mathrm{c}} \times 10^{1}$ & $3.14 \pm 0.06^{\mathrm{d}} \times 10^{2}$ & $1.03 \pm 0.15^{\mathrm{d}} \times 10^{3}$ & $3.25 \pm 0.18^{\mathrm{d}} \times 10^{4}$ & $3.16 \pm 0.54^{\mathrm{d}} \times 10^{5}$ \\
& $4.0 \%$ & $4.57 \pm 0.23^{\mathrm{d}} \times 10^{1}$ & $6.25 \pm 0.12^{\mathrm{e}} \times 10^{1}$ & $3.67 \pm 0.22^{\mathrm{e}} \times 10^{2}$ & $5.25 \pm 0.18^{\mathrm{e}} \times 10^{3}$ & $6.22 \pm 0.15^{\mathrm{e}} \times 10^{4}$ \\
\hline
\end{tabular}

Data are means \pm SD from triplicate experiments. ${ }^{\text {a-e }}$ Different letters indicate significant $(p<0.05)$ differences in the same row. 


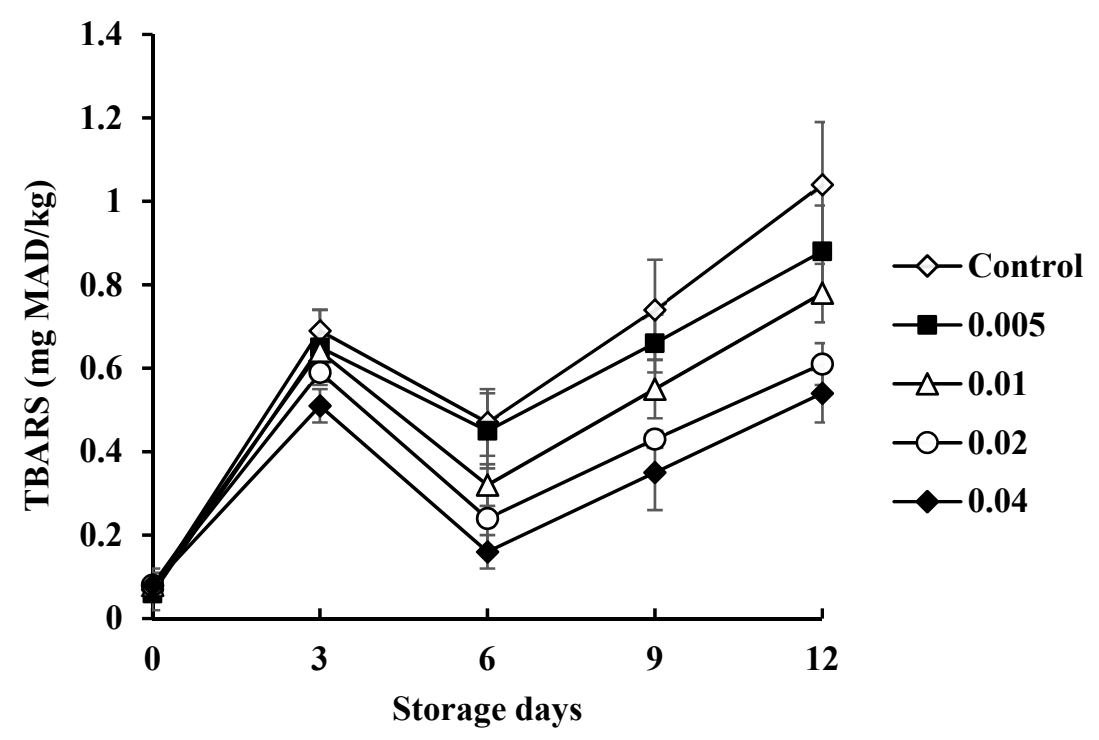

Figure 5. Effect of COSP on thiobarbituric acid reactive substance (TBARS) in white shrimp during refrigerated storage.

\subsection{Effect of COSP on the Physical Quality of Shrimp during Refrigerated Storage}

Hardness is one of the important textural parameters for consumer acceptability. The hardness changes of the control and COSP-treated shrimp during refrigerated storage are shown in Figure 6. The differences in hardness can result from increased bacterial content of aerobic bacterial, and interactions between COSP dipping solution and shrimp tissue caused changes in hardness. COSP-treated shrimp tended to be harder than the control, which indicates that COSP treatment was efficient in improving the physical properties of shrimp. Similar results were found for chitosan-coated oil sardine, chitosan-gelatin-coated shrimp, and green tea extract-treated shrimp [24-27]. Hardness was correlated linearly with the TVC of microbial species for control shrimp $\left(R^{2}=-0.97\right)$ and COSP-treated shrimp $\left(R^{2}=-0.94,-0.92,-0.96\right.$, and -0.97 for $0.5 \%, 1.0 \%, 2.0 \%$, and $4.0 \%$ COSP treatment, respectively) and control shrimp.

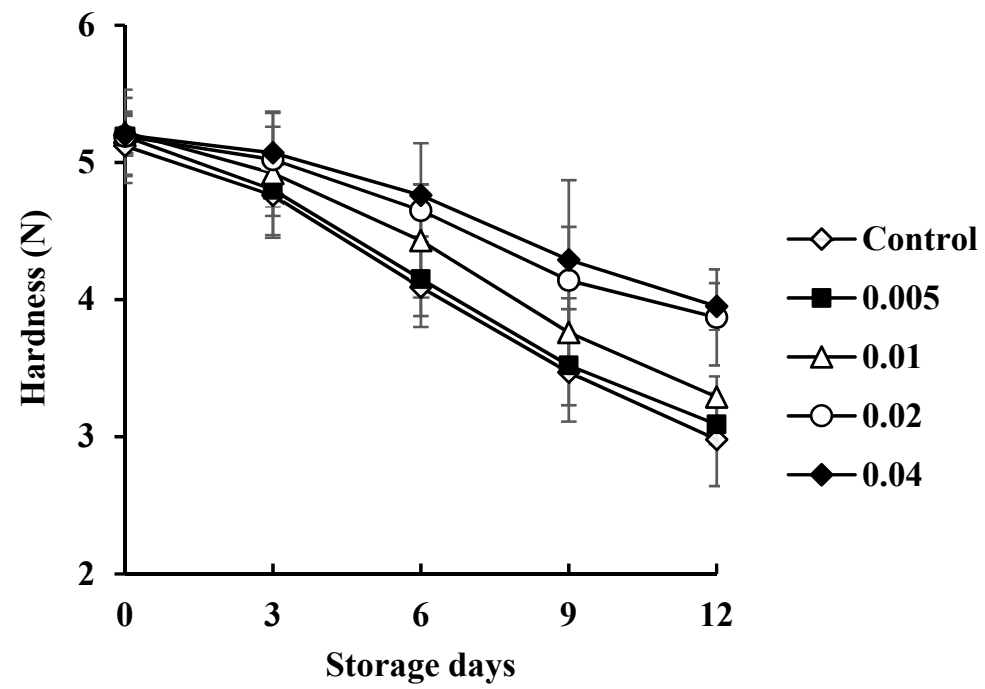

Figure 6. Changes in hardness of white shrimp treated with COSP during refrigerated storage.

The color analysis of COSP-treated and control shrimp during refrigerated storage is shown in Figure 7A. The $\mathrm{L}^{*}$ value of all samples decreased significantly during storage, as seen by the appearance of black spots. The decrease in $L^{*}$ value with time was slower for COSP-treated shrimp than the control. At the end of storage, the values were about eight 
points below the initial value for the control, but only two points below for COSP-treated shrimp. In previous studies, the presence of chitosan, gelatin, polysaccharides, and plant extract in dipping solution prevented the decreased lightness of color of shrimp [16]. The $\mathrm{L}^{*}$ values correlated with the TVC of microbial species in the control shrimp $\left(R^{2}=-0.95\right)$ and COSP-treated shrimp $\left(R^{2}=-0.93,-0.91,-0.94\right.$, and -0.92 for $0.5 \%, 1.0 \%, 2.0 \%$, and $4.0 \%$ COSP treatment, respectively).
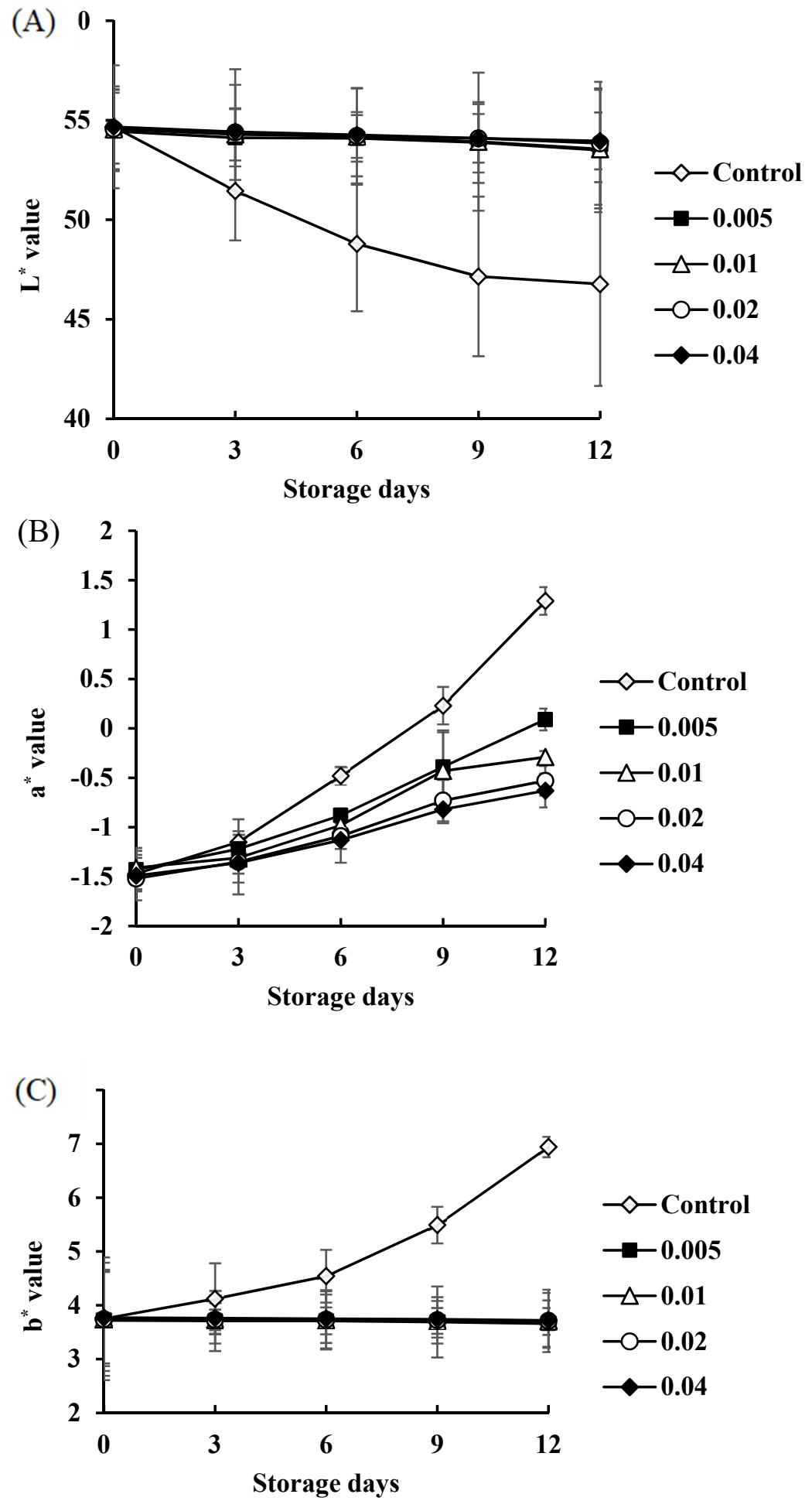

Figure 7. Changes in color properties of white shrimp treated with COSP during refrigerated storage. (A) $L^{*}$ values; (B) $a^{*}$ values; (C) $b^{*}$ values. 
The $\mathrm{a}^{*}$ values increased with increasing storage time, with a slower increase for COSPtreated shrimp, as shown in Figure 7B. The same increasing tendency with time for the $\mathrm{a}^{*}$ value was observed in shrimp; the color alters with the oxidation of lipids due to hydrolysis of astaxanthin by endogenous enzymes which is then released into the protein matrixes in muscle tissues [24]. The $\mathrm{a}^{*}$ value changes might be due to the enhanced passage of oxygen through the COSP barrier because of intermolecular interactions in the generated structural matrix. COSP treatment did not result in any significant changes in $b^{*}$ values, as shown in Figure 7C. COSP treatment could have contributed to the maintenance of yellowness throughout the storage period (Figure 8). Avocado seed extracts prevented an increase in the redness and yellowness of shrimp muscle during storage [28]. Use of a COSP coating had no important effect on yellowness but did increase lightness and redness for coated cod patties [29]. The $\mathrm{a}^{*}$ value was correlated with the TVC of microbial species $\left(R^{2}=0.98,0.94\right.$, $0.91,0.95$, and 0.97 ) in the control and $0.5 \%, 1.0 \%, 2.0 \%$, and $4.0 \%$ COSP-treated shrimp, respectively. The $b^{*}$ value was correlated with the TVC of microbial species $\left(R^{2}=0.96\right)$ in control shrimp.

Treatments 0

Control

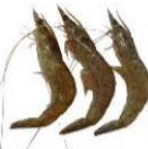

$0.5 \%$

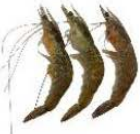

$1.0 \%$

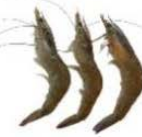

$2.0 \%$

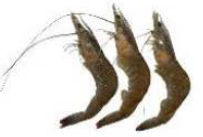

$4.0 \%$
3
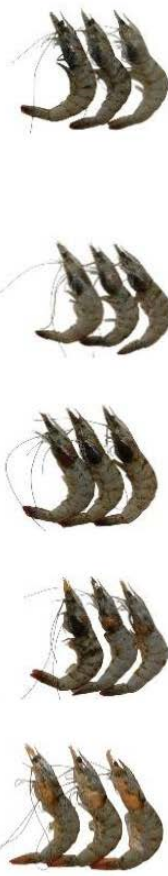

Storage days

6

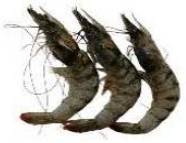

9 12
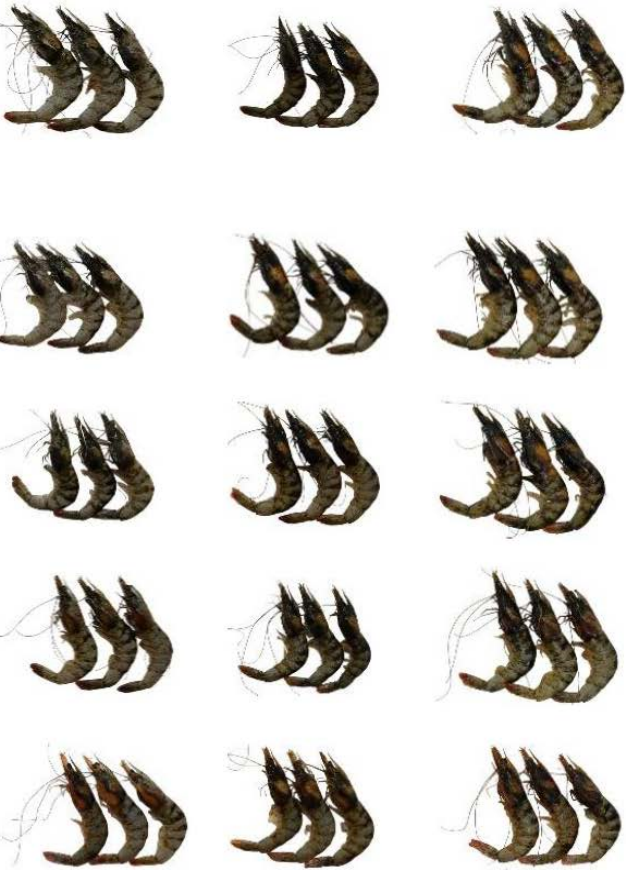

Figure 8. The appearance of white shrimp treated with COSP during refrigerated storage.

\subsection{Microbiological Analysis of Refrigerated Shrimp}

The TVCs of microbial species in shrimp with different COSP treatments during storage at $4{ }^{\circ} \mathrm{C}$ are presented in Table 2. The mean initial number of bacteria in fresh shrimp ranged from $4.57 \times 10^{1} \mathrm{CFU} / \mathrm{g}$ to $1.47 \times 10^{2} \mathrm{CFU} / \mathrm{g}$, close to the results of $10^{2}$ to $10^{3} \mathrm{CFU} / \mathrm{g}$ reported by Mace (2014) [30] and Liu (2016) [31]. During storage at $4{ }^{\circ} \mathrm{C}$, the mean TVC of the control shrimp rapidly increased to $2.34 \times 10^{4} \mathrm{CFU} / \mathrm{g}$ after 6 days of storage, faster than COSP-treated shrimp. From day 6 to day 12, the mean TVC in control shrimp increased quickly, to $1.58 \times 10^{8} \mathrm{CFU} / \mathrm{g}$ on day 12. COSP-treated shrimp showed significantly inhibited growth of bacteria during storage; the mean TVC with COSP $0.5 \%$ treatment was $8.22 \times 10^{7} \mathrm{CFU} / \mathrm{g}$ on day 12 , more than 10 times lower than that of the control, and mean TVC with COSP at $1.0 \%, 2.0 \%$, and $4.0 \%$ was $5.21 \times 10^{6} \mathrm{CFU} / \mathrm{g}$, $3.16 \times 10^{5} \mathrm{CFU} / \mathrm{g}$, and $6.22 \times 10^{4}, \mathrm{CFU} / \mathrm{g}$, respectively, also lower than the control value, and still under the organoleptically detectable level of $1 \times 10^{7} \mathrm{CFU} / \mathrm{g}$ [17]. 
Oyster shells consist of about $95 \%$ calcium carbonate $\left(\mathrm{CaCO}_{3}\right)$. After calcining, $\mathrm{CaCO}_{3}$ is converted into calcium oxide $(\mathrm{CaO})$ [4]. This has a good antibacterial effect via increased $\mathrm{pH}$ value during food preservation. Therefore, COSP is often used as a natural antibacterial agent. COSP could inhibit the growth of Staphylococcus aureus, Escherichia coli, Listeria, Salmonella, Cactus bacillus, Micrococcus luteus, Aspergillus niger, and Penicillium funiculosum [7]. It can be applied to preserve fresh-cut fruits and vegetables, in whole fish treatment, toothbrushes, antibacterial air conditioning filters, antibacterial fabrics, and cleaning cloths. High-temperature treatment of oyster shell powder (calcined at $900{ }^{\circ} \mathrm{C}$ for $5 \mathrm{~h}$ ) at $1.25 \%$ had antibacterial effects on food pathogens (E. coli, S. aureus, Salmonella typhimurium, and Vibrio parahaemolyticus), and the bacteriostatic zone can reach $>10.0 \mathrm{~mm}$ in diameter. Using oyster shell powder burned at $800{ }^{\circ} \mathrm{C}$ for $5 \mathrm{~h}$, a concentration of $1 \%$ could reduce the weight of mold (A. niger) hyphae. Hard bean curd and frozen tofu treated with $0.5 \%$ shell powder (calcined at $900{ }^{\circ} \mathrm{C}$ for $5 \mathrm{~h}$ ) had a lower total bacterial count than commercially available hard bean curd after 28 days, reduced to $4.19 \times 10^{6}$ and $4.16 \times 10^{5} \mathrm{CFU} / \mathrm{mL}$, respectively [14].

\section{Conclusions}

This study investigated the effect of COSP treatment on the quality of refrigeratorstored white shrimp (L. vannamei). This is the first report on the biochemical and physical attributes of COSP-treated refrigerator-stored shrimp. COSP treatment affected the $\mathrm{pH}$, TVB-N, PV, TBARS, hardness, color ( $\mathrm{L}^{*}, \mathrm{a}^{*}$ and $\mathrm{b}^{*}$ values), and TVC of microbial species in refrigerator-stored shrimp. The mechanism of preservation for COSP treatment might be the $\mathrm{CaOH}$ that was formed from $\mathrm{CaO}$ in the dipping solution, which resulted in increased $\mathrm{pH}$ and inhibited the growth of bacteria, as indicated by a lower increase in TVC in the COSP-treated shrimp than in the controls, and changed the activity of enzymes in shrimp muscle, thus resulting in a lower increase in biochemical and physical attributes. Hence, COSP dipping solution treatment was effective in reducing the spoilage and prolonging the shelf-life of seafood, which might provide processors or distributors with viable options for preservatives to improve the microbiological safety and quality of shrimp.

Author Contributions: Conceptualization, C.-W.H., C.-C.R.W., and P.-H.L.; data curation, C.-S.C., A.T.M., and P.-H.L.; formal analysis, W.-C.L., D.H.T.L., and P.-H.L.; funding acquisition, P.-H.L.; investigation, W.-C.L., Y.-J.C., and D.H.T.L.; methodology, W.-C.L., C.-W.H., Y.-J.C., Z.-C.L., C.-C.R.W., and D.H.T.L.; project administration, Y.-J.C. and P.-H.L.; resources, Z.-C.L.; writing—original draft preparation, W.-C.L. and Y.-J.C.; writing-review and editing, C.-S.C., C.-W.H., Z.-C.L., C.-C.R.W., and P.-H.L. All authors have read and agreed to the published version of the manuscript.

Funding: This work was financially supported by Mirthful Biotech Ltd.

Institutional Review Board Statement: Not applicable.

Informed Consent Statement: Not applicable.

Data Availability Statement: MDPI Research Data Policies at https:/ /www.mdpi.com/ethics (15 January 2022).

Acknowledgments: This study was supported by Mirthful Biotech Ltd.

Conflicts of Interest: The authors declare no conflict of interest.

\section{References}

1. Cakli, S.; Kilinc, B.; Cadun, A.; Dincer, T.; Tolasa, S. Quality differences of whole ungutted sea bream (Sparus aurata) and sea bass (Dicentrarchus labrax) while stored in ice. Food Control 2007, 18, 391-397. [CrossRef]

2. Dehghani, S.; Hosseini, S.V.; Regenstein, J.M. Edible films and coatings in seafood preservation: A review. Food Chem. 2018, 240, 505-513. [CrossRef] [PubMed]

3. Smith, S.; Varble, S.; Secchi, S. Fish Consumers: Environmental Attitudes and Purchasing Behavior. J. Food Prod. Market. 2017, 23, 267-282. [CrossRef]

4. Silva, T.H.; Mesquita-Guimarães, I.; Henriques, B.; Silva, F.S.; Fredel, M.C. The potential use of oyster shell waste in new value-added by product. Resources 2019, 8, 13. [CrossRef] 
5. Kim, Y.; Choi, Y.; Noh, D.; Cho, S.; Suh, H.J. The effect of oyster shell powder on the extension of the shelf life of tofu. Food Chem. 2007, 103, 155-160. [CrossRef]

6. Choi, Y.; Whang, J.; Kim, J.; Suh, H.J. The effect of oyster shell powder on the extension of the shelf-life of Kimchi. Food Control 2006, 17, 695-699. [CrossRef]

7. Oikawa, K.; Asada, T.; Yamamoto, K.; Wakabayashi, H.; Sasaki, M.; Sato, M.; Matsuda, J. Antibacterial Activity of Calcined Shell Calcium Prepared from Wild Surf Clam. J. Health Sci. 2000, 46, 98-103. [CrossRef]

8. Sadeghi, K.; Park, K.; Seo, J. Oyster Shell Disposal: Potential as a Novel Ecofriendly Antimicrobial Agent for Packaging: A Mini Review. Korean. J. Packag. Sci. Technol. 2019, 25, 57-62. [CrossRef]

9. Guo, M.; Jin, T.Z.; Yang, R.; Antenucci, R.; Mills, B.; Cassidy, J.; Scullen, O.J.; Sites, J.E.; Rajkowski, K.T.; Sommers, C.H. Inactivation of natural microflora and inoculated Listeria innocua on whole raw shrimp by ozonated water, antimicrobial coatings, and cryogenic freezing. Food Control 2013, 34, 24-30. [CrossRef]

10. Okpala, C.O.R. Investigation of quality attributes of ice-stored pacific white shrimp (Litopenaeus vannamei) as affected by sequential minimal ozone treatment. LWT-Food Sci. Technol. 2014, 57, 538-549. [CrossRef]

11. AOAC. Official Methods of Analysis, 17th ed.; Association of Official Analytical Chemists International: Rockville, MD, USA, 2000; Volume II, Chapter 39; pp. 1-27.

12. Wang, H.B. Effect of dandelion polysacchardies on the retardation of the quality changes of white shrimp. Int. J. Biol. Macromol. 2014, 68, 205-208. [CrossRef] [PubMed]

13. AOCS. Official Methods and Recommended Practices of the American and Chemists Society, 4th ed.; AOCS: Champaign, II, USA, 1990.

14. Tongwanichniyom, S.; Pattamapitoon, T.; Sangvichien, N.; Phornphisutthimas, S. Production of calcium oxide from waste oyster shells for a value-added application of antibacteria. Ecol. Enviroment Conserv. 2021, 27, 539-549.

15. Nirmal, N.P.; Benjakul, S. Retardation of quality changes of Pacific white shrimp by green tea extract treatment and modified atmosphere packaging during retrigerated storage. Int. J. Biol. Macromol. 2011, 149, 247-253.

16. Arancibia, M.Y.; López-Caballero, M.E.; Gómez-Guillén, M.C.; Montero, P. Chitosan coatings enriched with active shrimp waste for shrimp preservation. Food Control 2015, 54, 259-266. [CrossRef]

17. Farajzadeh, F.; Motamedzadegan, A.; Shahidi, S.; Hamzeh, S. The effect of chitosan-gelatin coating on the quality of shrimp (Litopenaeus vannamei) under refrigerated condition. Food Control 2016, 67, 163-170. [CrossRef]

18. Nowzari, F.; Shábanpoun, B.; Ojagh, S.M. Comparison of chitosan-gelatin composite and bilayer coating and film effect on the quality of refrigerated rainbow trout. Food Chem. 2013, 141, 1667-1672. [CrossRef]

19. Klinmalai, P.; Fong-in, S.; Phongthai, S.; Klunklin, W. Improving the quality of frozen fillets of semi-dried Gourami Fish (Trichogaster pectoralis) by using sorbitol and citric Acid. Foods 2021, 10, 2763. [CrossRef]

20. Jeon, Y.J.; Kamil, J.Y.; Shahidi, F. Chitosan as an edible invisible film for quality preservation of herring and Atlantic cod. J. Agric. Food Chem. 2002, 20, 5167-5178. [CrossRef]

21. Sathiel, S.; Liu, Q.; Huang, J.; Prinyawiwatkul, W. The influence of chitosan glazing on the quality of skinless pink salmon (Oncorhynchus garbuscha) fillets during frozen sotrage. J. Food Eng. 2007, 83, 366-373. [CrossRef]

22. Dirapan, P.; Boonyakiat, D.; Poonlarp, P. Improving shelf life, maintaining quality, and delaying microbial growth of broccoli in supply chain using commercial vacuum cooling and package icing. Horticulturae 2021, 7, 506. [CrossRef]

23. Aziman, N.; Jawaid, M.; Mutalib, N.A.A.; Yusof, N.L.; Nadrah, A.H.; Nazatul, U.K.; Tverezovskiy, V.V.; Tverezovskaya, O.A.; Fouad, H.; Braganca, R.M.; et al. Antimicrobial potential of plastic films incorporated with sage extract on chicken meat. Foods 2021, 10, 2812. [CrossRef] [PubMed]

24. Bindu, J.; Ginson, J.; Kamalakanth, C.K.; Asha, K.K.; Srinivasa Gopal, T.K. Physicochemical changes in high pressure coated Indian white prawn (Fenneropenacus indicus) during chill storage. Innov. Food Sci. Emerg. 2013, 17, 37-42. [CrossRef]

25. Speranza, B.; Racioppo, A.; Bevilacqua, A.; Buzzo, V.; Marigliano, P.; Mocerino, E.; Scognamiglio, R.; Corbo, M.R.; Scognamiglio, G.; Sinigaglia, M. Innovative preservation methods improving the quality and safety of fish products: Beneficial effects and limits. Foods 2021, 10, 2854. [CrossRef] [PubMed]

26. Firdous, A.; Ringø, E.; Elumalai, P. Effects of green tea- and amla extracts on quality and melanosis of Indian white prawn (Fenneropenaeus indicus, Milne Edwards, 1837) during chilled storage. Aquac. Fish. 2021, 6, 617-627. [CrossRef]

27. Nagarajan, M.; Rajasekaran, B.; Benjakul, S.; Venkatachalam, K. Influence of chitosan-gelatin edible coating incorporated with longkong pericarp extract on refrigerated black tiger Shrimp (Penaeus monodon). Cur. Res. Food Sci. 2021, 4, 345-353. [CrossRef]

28. Do, D.T.B.; Bui, T.H.; Phan, D.T.A. Persea Americana Mill seed extracts: Understanding insights into the antioxidant and antityrosinase activities and effects on preserving qualities of whiteleg shrimp (Litopenaus vannamei) during refrigerated storage. Food Chem. 2022, 373, 131469. [CrossRef]

29. Kontominas, M.G.; Badeka, A.V.; Kosma, I.S.; Nathanailides, C.I. Innovative seafood preservation technologies: Recent developments. Animals 2021, 11, 92. [CrossRef]

30. Mace, S.; Cardinal, M.; Jaffres, E.; Cornet, J.; Lalanne, V.; Chevalier, F.; Sérot, T.; Pilet, M.; Dousset, X.; Joffraud, J. Evaluation of the spoilage potential of bacterial isolated from spoiled cooked whole tropical shrimp (Penaeus vannamei) stored under modified atmosphere packaging. Food Microbiol. 2014, 40, 9-17. [CrossRef]

31. Liu, X.; Jia, Y.; Hu, Y.; Xia, X.; Li, Y.; Zhou, J.; Liu, Y. Effect of Citrus wilsonii Tanaka extract combined with alginate-calcium coating on quality maintenance of white shrimps (Litopenaeus vannamei Boone). Food Control 2016. [CrossRef] 